\title{
A view on 50 years of life of the ISI: With a focus on ISI relations with official statistics ${ }^{1}$
}

\author{
Jean-Louis Bodin \\ Former President of ISI (1999-2001) and IAOS (1989-1991), Inspecteur Général de l'INSEE Honoraire, Paris, \\ France \\ E-mail: jean-louis.bodin@yahoo.fr
}

This paper does not claim to be a history of statistics, nor even a detailed history of the International Statistical Institute (ISI). It is based on the testimony of an official statistician who has participated in the activities and life of the ISI since its $37^{\text {th }}$ session $^{2,3}$ held in London in $1969^{4}$ and has contributed more or less actively to all our congresses since the $40^{\text {th }}$ session held in Warsaw in 1975.

It mostly focuses on the role of the ISI in the domain of official statistics and presents some issues that have marked in the eyes of its author the life of the ISI for the past five decades in the domain of official statistics. Beforehand, the author chose to describe the main events that occurred during the historical relations between official statistics and ISI until 1969. The his-

\footnotetext{
${ }^{1}$ This article was presented as an invited paper at a session on ISI History during the $62^{\text {nd }}$ ISI World Statistical Congress held in Kuala Lumpur, Malaysia in August 2019.

${ }^{2}$ The name of the World Statistical Congresses of the ISI were "ISI Sessions" until the revision of the Statutes adopted during the $58^{\text {th }}$ ISI session held in Dublin in 2011. The $59^{\text {th }}$ ISI session held in Hong-Kong in 2013 was therefore the first WSC of the new era.

${ }^{3}$ The $37^{\text {th }}$ ISI Session was inaugurated by Sir Harold Wilson, UK Prime Minister. During his speech, Sir Harold reminded that he was Director of Economics and Statistics at the Ministry of Fuel and Power in 1943-1944 before his first election at the Commons (1946). Later, he was elected as the President of the Royal Statistical Society (1972-73).

${ }^{4}$ The years ending in 9 have all been especially important for the author: 2019 is the fiftieth anniversary of his first participation in a session of the ISI, the fortieth anniversary of his election as a member of the ISI, the thirtieth anniversary of the beginning of his term as IAOS President and the twentieth anniversary of the beginning of his term as President of the ISI.
}

tory of ISI before this date allows shedding light on the issues mentioned by the author in the second part of this paper.

\section{A brief history of the ISI between its foundation and 1969 and its relations with official statistics [1-3]}

The ISI was formally established in June 1885 during the Jubilee of the Statistical Society of London and the $25^{\text {th }}$ anniversary of the Paris Statistical Society with the participation of about twenty countries, almost all European and North-American. ${ }^{5}$ Prof. Franz von Neumann-Spallart (Austria) presented on this occasion a paper sketching a plan for an international statistical association.

In fact this creation was only a logical continuation of the holding of the nine International Statistical Congresses (ISC) organized between 1853 and $1876^{6}$ in European or North American cities. The first of these conferences was held in Brussels following an initiative taken by Adolphe Quételet (Belgium) and Prince Albert, consort of Queen Victoria, during the Universal Exhibition organized in London two years earlier.

\footnotetext{
${ }^{5}$ On the occasion of its 135 th anniversary, the ISI publishes in 2020 on its website short articles on the events that led to its foundation.

${ }^{6}$ No congress was organized between 1876 and 1885 since the German Empire and its Kingdom of Prussia were not happy with the management of the Permanent Commission of the ISCs; they refused to participate in any international statistical conference. That was probably more a political disagreement than a technical one.
} 
When ISC and ISI were created, most of their objectives were oriented towards what is called today official statistics: international comparisons, development of classifications, population censuses... In his opening address of the $4^{\text {th }}$ ISC held in London in 1860 Prince Albert stated that "these congresses pave the way to an agreement among different governments and nations to follow up common inquiries, in a common spirit, by a common method for a common end". This statement is still today a strong recommendation of all international and supranational organisations to their country members. One of the first tasks of the newly created ISI was the production of an International Statistical Directory, which is mainly today into the hands of international agencies such as the UN, the World Bank or regional development banks.

Another important achievement of the ISC/ISI before the $1^{\text {st }}$ World War was the production of statistical classifications. The oldest classification to have come into existence was the International Classification of Diseases and Causes of Death [4]. First discussions about this classification were made during the $1^{\text {st }}$ ISC in Brussels in 1853 among the different subjects that could be candidates for international statistical comparisons. The $4^{\text {th }}$ ISI session in Vienna (1891) marked the beginning of true international acceptance of statistical lists of causes of death and sickness. Jacques Bertillon, Chief of Statistics for the City of Paris, ${ }^{7}$ was asked to chair a committee that would prepare a list for causes of death at the next ISI meeting; this classification was adopted in 1893 during the $5^{\text {th }}$ ISI session in Chicago. Early in the history of this classification, a revision cycle was established to keep the list abreast of medical progress. In 1899 , during its $7^{\text {th }}$ session in Christiana (former name of the city of Oslo) ISI approved the proposal made by American Public Health Association for a decennial revision of the list. Nowadays maintenance and revision of this classification are made by the World Health Organisation (WHO) based in Geneva.

An interesting controversy took place in the last decade or the $19^{\text {th }}$ century about "representative methods". This controversy followed a paper presented by Nicolai Kiær, director of the Norwegian Central Bureau of Statistics, during the $5^{\text {th }}$ ISI session in Bern (1895): Observations and Experiments concerning Represen-

\footnotetext{
${ }^{7}$ Jacques Bertillon was the grandson of Achille Guillard who investigated the decision to prepare a uniform disease classification during the $1^{\text {st }}$ ISC.
}

tative Counts. ${ }^{8}$ The reactions of the ISI General Assembly against Kiær's paper were violent and Kiær's proposals were refused almost unanimously. Kiær reiterated his proposals during the $6^{\text {th }}$ session in St. Petersbourg in 1897 and the $8^{\text {th }}$ session in Budapest in 1901 with the same results despite support of Scandinavian and French delegates. After 1903, sampling methods were excluded of the agenda of the ISI sessions until the $16^{\text {th }}$ session in Rome (1925) where the ISI General Assembly approved the conclusions of a committee (Adolphe Jensen, Corrado Gini and Lucien March were among the members of this committee) in favour of these methods.

Another controversy arose during $13^{\text {th }}$ ISI session in The Hague when the General Assembly decided to create a Permanent Office, precisely in this city. An ad hoc Committee was appointed and its rapporteur, the French Lucien March, wrote that our institute cannot remain an exclusively academic institution, while the movement of ideas and activities gives rise to ever more pressing needs for statistical information. Some participants announced "the suicide of our Society" since they feared that "the setting-up of a permanent office would limit the independence of the ISI" (it was expected that the operating costs of the permanent office would be covered by government contributions). Fortunately, the existence of this office prevented the ISI from exploding during the First World War: it was located in the Netherlands which was a neutral country, but the President and one vice-president were from allied countries while one other vice-president was German.

This role played by ISI could have changed when the League of Nations ${ }^{9}$ (SDN) was set up after the signing of the Treaty of Peace in Versailles in 1919. One of its first acts was to appoint an International Statistical Commission which met in Paris in October 1920 with significant ISI participation. ${ }^{10}$ This collaboration gave rise to difficult discussions; some ISI members believed that a learned society should not have to work with an intergovernmental organization on pain of losing its scientific freedom. Another point of view, expressed by Willcox, ISI Vice-president from 1923 to 1947, was that during this period the role of the ISI was that of a

\footnotetext{
${ }^{8}$ The original version of this paper was presented in French under the title Observations et expériences concernant des dénombrements représentatifs. French and German were at that time the two main languages of the ISI.

${ }^{9}$ The League of Nations is best known by its French acronym: SDN (for Société des Nations).

${ }^{10}$ This Commission was chaired by the ISI President Luigi Bodio (Italy) and its Vice-president Albert Delatour (France).
} 
"semi-governmental" body. My impression is that these problems have weakened the role of the ISI vis-à-vis the official statistics between the two World Wars, but without compromising its role as a forum for research in probability and mathematical statistics (e.g. the paper on theory of tests presented by Jerzy Neyman during the $22^{\text {nd }}$ ISI session in London in 1934). The outbreak of the $2^{\text {nd }}$ Word War (1939) created a new crisis in the affairs of the ISI. The $24^{\text {th }}$ session convened in Prague in September 1938 closed prematurely because of Hitler's ultimatum sent to the Czechoslovak government. The occupation of the Netherlands by the German forces put an end to all ISI activities; fortunately, the ISI office and its archives were transferred to the Peace Palace which was an exterritorial place.

After the creation of the United Nations in October 1945, it was decided to create the UN Statistical Division (UNSD) at the UN Headquarters. Otherwise, the US government had five years previously invited the ISI to hold its $25^{\text {th }}$ session in Washington, DC, in 1940. Of course it was not possible to organize it. But the Arrangements Committee set up in 1939 for that session merged with the UN, the ISI and other bodies into an Arrangements Committee for International Statistical Conferences. Prof. Stuart Arthur Rice played a fantastic role in this committee; he played a leading role in reactivating ${ }^{11}$ the ISI from 1945 onwards, in particular in drafting new statutes and his invaluable efforts were recognized by his election as ISI President in $1947 .{ }^{12}$ At the same time, he chaired the UN nuclear session held in October 1946 at Hunter College in New York which made recommendations for the composition and terms of an UN Statistical Commission ${ }^{13}$ (UNSC). According to J.W. Nixon, three names have stood out the history of the ISI, Adolphe Quételet with the foundation of the ISC in 1853, Franz von Neumann-Spallart who drafted the first ISI Statutes in 1885 and Stuart Arthur Rice.

Influencing governmental statistical agencies by encouraging uniformity in statistical definitions and data collection was certainly one of the main roles of the ISI before the $1^{\text {st }}$ Word War, but after 1945, this role was taken over by the UN. The mission of the ISI became international communication among statisticians rather than among governments, international promo-

\footnotetext{
${ }^{11}$ Stuart A. Rice also initiated in 1940 the Inter American Statistical Institute (IASI) which still exists today and is the most active regional society affiliated to the ISI.

${ }^{12}$ Stuart A. Rice was re-elected ISI President in 1949 and 1951 and elected Honorary President in 1953.

${ }^{13}$ The UN Statistical Commission held its $50^{\text {th }}$ session this year (2019) at the UN Headquarters in New York.
}

tion and development of research, statistical capacity and good practice across all statistical domains. ISI has had consultative status with the UN Economic and Social Council since 1949 and therefore with the UN Statistical Commission. Similar links may be identified with regional and specialized UN bodies, such as the Conference of European Statisticians which is a subsidiary body of the UN Economic Commission for Europe in Geneva, FAO, ILO, UNESCO and others.

After Stuart A. Rice, many ISI leaders were not only involved with the ISI as Presidents or other leading role, including within the ISI associations/sections, but also chaired the UNSC or the Conference of European Statisticians, e.g. Petter Jacoj Bjerve (Norway), Prasanta Chandra Mahalanobis (India), Rao (India), Mikhail Antonovitch Korolev (USSR), Vera Nyitrai (Hungary), Edmond Malinvaud (France), or more recently William Begeer (the Netherlands), Carlos Jarque (Mexico), or Shigeru Kawasaki (Japan). Sir Harry Campion (UK) is another example: after helping setting up the UNSD and being its first head, he also chaired the UNSC in 1951 and 1952 and was ISI President from 1963 to 1967.

\section{Presentation of some issues concerning official statistics that have marked in my eyes the life of the ISI for the past five decades}

This chapter does not purport to comprehensively cover all areas of intercourse between the ISI and official statistics, but illustrates some of these interactions.

The ISI General Assembly convened during the $41^{\text {st }}$ ISI Session in Delhi, India, in 1977, established a Committee on Future Directions. This committee, chaired by Joseph Duncan ${ }^{14}$ presented its report [5] during the $42^{\text {nd }}$ session in Manila, Philippines. They made the following main recommendations:

1. The fundamental mission of the ISI will be to serve as the premier international academy of statisticians with a special focus on asserting a highly professional and moral tone on statistical issues of wide-spread public interest and in promoting the development of the professions.

2. The ISI of the future will regard the integration of statistics as one of its major objectives. ${ }^{15}$

\footnotetext{
${ }^{14}$ Joe Duncan was in 1977-1979 director of the Office of Federal Statistical Policy and Standards, at the US Department of Commerce.

${ }^{15} \mathrm{An}$ ad-hoc committee on the integration of statistics was established during the $40^{\text {th }}$ session in Warsaw in 1975 and presented its conclusions in the same time as those of the Committee on Future Directions in Manila.
} 
3. The ISI will create search committees in an effort to extend its membership to the developing countries and thereby broaden the geographic representation of its membership.

4. The professional competence of the ISI membership will be utilized in service to international organizations, national governments and others through an organized program of research and development and consultation, and the creation of the International Center for Research and Development in Statistics.

5. Statistical education and training will continue to be a major role of the ISI in the future: the major focus of such activity will shift from the developed to the developing countries.

6. ISI will undertake regional programs to expend its influence in the developing regions of the world and to recognize the specific needs of the individual regions.

7. ISI will seek to strengthen its sections and integrate their programs into the whole fabric of the Institute.

8. ISI will seek to strengthen its relationship to national statistical societies and ensure that there is a minimum of overlap or duplication in the functions of professional societies at the national and international level.

These eight recommendations (among over 85 specific recommendations) are still topical forty years after their presentation.

The decade between 1969 and 1979 that ended by the presentation of these recommendations in Manila has seen important changes in the ISI governance:

- After 1975, it was decided that the term of ISI Presidents will be limited to two years, but the Presidents will be elected two years before the beginning of their term and serve as President-Elect; an Executive Committee and an elected Council replaced the Bureau.

- The creation of sections (now associations) was encouraged; among them sections dealing with some aspects of official statistics: in 1973 International Association of Survey Statisticians (IASS), in 1985 International Associations for Official Statistics (IAOS) and in 1995 the Irving Fisher Committee on Central Banks Statistics. The Presidents of sections may participate in ISI EC and Council meetings as observers.

Before the creation of IAOS, there were other ISI sections dealing more or less with official statistics, for instance, IASS or IASC (International Association for Statistical Computing) Statisticians). These other sections are grouping statisticians interested by the development of methods in their domain. The objective of IAOS was different: several people insisted on giving to this new section the name of International Association for Official Statistics and not International Association of Official Statisticians. That means that its founding members hoped that IAOS would be open not only to official statisticians but also to the users of official statistics and more generally to all those who are interested by the role of statistics in the society. These goals are still very relevant after 35 years. I was one of the IAOS founding members with Vera Nyitray, President in 1985 of the Központi Statisztikai Hivatal (KSH - Central Bureau of Statistics); she was also happy to create an independent forum where statisticians coming from both sides of the Iron Curtain may discuss in a neutral place and a scientific atmosphere.

In 1979, it was decided to build a set of ethical principles and good practices and a committee in charge of preparing an ISI Declaration on Professional Ethics [6] was established. One of the first attempts to formalise ethical rules was certainly the ASA Code of Conduct for Statisticians adopted in 1979 by the American Statistical Association under the leadership of W. Edwards Deming (now, after a revision in 1989, the ASA Ethical Guidelines for Statistical Practice). W.E. Deming was also, with Roger Jowell (UK), one of the promoters of the ISI Committee. These two codes are very general and apply not only to official statisticians but also to the statistical community at large (academic statisticians, researchers, statisticians working in industry, etc.) and don't take into account three specific characteristics of official statistics:

- Official statisticians do not work for a specific consumer or a small group of users; they receive public funds to be at the service of the society at large and to contribute in their domain to the Citizens' Right to Information.

- The individuals' Right to Privacy very often conflicts with the society's Right to Information (in order to know its collective characteristics).

- The bodies responsible for official statistics have a dual authority, a scientific authority and an administrative authority.

During the preparation of the declaration, a divergence arose in particular concerning the mandatory nature of surveys, which is often the case in official surveys, and on the concept of 'informed consent'. 
The ISI Declaration was adopted during the Centenary ISI Session (45 ${ }^{\text {th }}$ session) held in Amsterdam in 1985. An ISI Committee on Ethics was established but was not very active until 2000. It was reactivated following the holding in Buenos Aires in June, 1998, of an international conference intended to bring the support of the international community to INDEC (Instituto Nacional de Estadística y Censos) after the strong attacks of the President of the Argentine Nation on employment surveys. After careful work by this committee, a revised and modernized version of the ISI Declaration on Professional Ethics was approved by the ISI Council in July 2010 and formally presented on World Statistics Day on 20 October 2010. The same year the committee's activities were terminated and an ISI Advisory Board on Ethics [7] (ABE) was established to advise the ISI EC and Council on relevant ethical issues and to recommend or undertake activities for promoting observance of ethical principles in statistics. Most of the work of the ABE since its creation concerned official statistics (e.g. manipulation of the CPI in Argentina between 2008 and 2015, or deletion of the long form in the Canadian census in 2010). In addition, the ABE also intervened to defend statisticians unfairly prosecuted while they had done their work properly; the iconic cases were those of Graciela Bevacqua (Argentine) and Andreas Georgiou (Greece).

The fall of the Berlin Wall and the collapse of the communist systems in 1989 had huge consequences; the market-oriented system obliged a far greater number of people with economic and social responsibilities in society to take decisions. Such decisions implied the use of an adequate information system and, in particular, sound and relevant statistical information. Moreover, it was vital for statisticians to gain the confidence of the public in the information they were to produce. In the early months of 1990, statisticians from Central and Eastern Europe were fully aware that it was not so easy to face this new challenge and to gain this indispensable trust of the public. They were looking for new references, new landmarks, to serve as a framework in which to fulfill their duties. Such references were maybe not so different from the strictly technical point of view, but totally different where the concept itself of the role of statisticians in the society was concerned. The reaction of the statistical community to this concern was very rapid. The Bureau of the UN Conference of European Statisticians (CES) decided to organize a consultation and a workshop during the first semester of 1990 [8]. The ISI appointed a representative to the working group ${ }^{16}$ that was created to prepare a document to be submitted to the CES. The terms of reference of the working group asked it to take into account "in particular the work done by the ISI on ethical guidelines for statisticians". The result of this work was the "Fundamental Principles of Official Statistics" that was endorsed by the $39^{\text {th }}$ session of the CES in June 1991 then adopted by one of the Conference's parent bodies, the UN Economic Commission for Europe, during its $47^{\text {th }}$ plenary session in April of 1992. Shortly after, it was recognized that these Principles have a universal value and a global significance. Following an international consultation process, a milestone in the history of international statistics was reached when the UN Statistical Commission (UNSC) at its Special Session in April 1994 adopted the very same set of principles - with a revised preamble - as the UN Fundamental Principles of Official Statistics. At its 42nd session in 2011, the UNSC acknowledged that the Principles were still as relevant today as they had been in the past and that no revision of the ten Principles themselves was necessary. The Commission recommended, however, updating the preamble in order to take into account new developments since 1994 and adopted the revised preamble at its $44^{\text {th }}$ session in 2013. In July 2013 the UN Economic and Social Council adopted the Principles on UNSC recommendation and, pursuant to its recommendation, the UN General Assembly, in its resolution 68/261 of 29 January 2014, endorsed the Fundamental Principles of Official Statistics [9]. The ISI played an important role in the preparation, dissemination and popularization of the Principles that are an important work tool for the Committee on Professional Ethics, then for the Advisory Ethical Board when instructing specific files. An important number of papers during ISI sessions, then ISI World Statistical Congresses, were prepared and presented.

Official statisticians have long been more than reluctant to engage into the measurement of "sensitive political issues" [10]. For a long time, they considered that involving statistics in human rights or democratic governance assessments would endanger their "scientific neutrality". This reluctance had also been linked to the quite rudimentary basis of the methods used by human rights activists. The first significant impulse for involving official statisticians in human rights issues was given by the ASA with the creation in late 1970s

\footnotetext{
${ }^{16}$ In addition to the ISI representative, there were representatives of Poland (chair), France (vice-chair), Bulgaria, Romania, Spain, Switzerland and Turkey.
} 
of its Standing Committee on Scientific Freedom and Human Rights as a reaction to the disappearance and assassination of Carlos Noriega, director of the INDEC, by the Argentinean military dictatorship. Most of the founding members of this ASA Committee expected an enlargement of its action towards exploring possible applications of statistics to monitor the status of human rights; nevertheless they were refrained from engaging the Committee in this path until 1985. At the global level, the ISI started by opposing strong resistance to attempts by some of its members to involve in more human right. In 1981, since the $43^{\text {rd }}$ ISI session was organized in Buenos Aires, the Prof. Edmond Malinvaud, President of the ISI, expressed ISI members' concerns about Carlos Noriega's disappearance to the President of the Argentinean Nation through a visit to the Argentinean Ambassador in Paris. Four years later, a contributed paper meeting on Statistics, Statisticians and Human Rights, was initially accepted and scheduled for the 1985 ISI session in Amsterdam, but the ISI EC later decided to remove it from the official program and it was held as an informal gathering. During years, this reluctance to mix scientific statistical work with "sensitive political issues" was broadly shared within the ISI. It was only in 1999, IAOS decided that its 2000 Independent Conference be devoted to the use of statistics to assess human rights and some aspects of democratic governance, in particular in the context of development processes. Nowadays such works have largely been done within ISI, IAOS and the statistical community at large.

For a long time, the ISI has been actively helping to build statistical capacity in developing countries. The ISI EC produced in 2013 a so-called White Paper on Statistical Capacity Building (SPC). ISI has been proactive in organizing several workshops on leadership and management in different regions (Anglophone Africa in Addis Ababa, Ethiopia, in 2011 and Dar El Salaam, Tanzania, in 2015; Francophone Africa in Dakar, Senegal, in 2012, Yaoundé, Cameroon, in 2016, and Tunis, Tunisia, in 2019; Eastern Asia in Daejon, Korea, in 2012). ISI also organized topical workshops, e.g. on poverty in Kathmandu, Nepal, in 2017 or I sponsored or co-sponsored national activities. The ISI Committee on SPC is also one of the partners for the organization of the UN World Data Forum that is a suitable platform for intensifying cooperation with various professional groups, such as information technology, geospatial information managers, data scientists, and users, as well as civil society stakeholders. Two Forums were already organized in Cape Town, South Africa, in 2016, then in
Dubai, United Arab Emirates, in October 2018. The ISI is involved in the third session of this Forum that will be held in Bern, Switzerland, in October 2020.

\section{Conclusion}

The ISI has proven through its long history of more than a century and a half ${ }^{17}$ that, among all the fields of theoretical statistics and applied statistics, it could also bring the experience of all its members to the development of the official statistics, in all regions of the world, and in particular in developing countries, without jeopardizing its other activities. The cooperation between the ISI and statistical institutions at both national and international levels is a very good example for a common work between NGOs and official bodies.

\section{References}

[1] Nixon J.W. A History of the ISI 1885-1960 ISI publications, The Hague 1960.

[2] History of the ISI - ISI Website: https://www.isi-web.org/ima ges/WSC/2013/ISI\%20History\%20Brochure.pdf.

[3] Droesbeke J.-J. and Tassi P.H. Histoire de la Statistique, Collection Que Sais-je? PUF, Paris 1990.

[4] History of the Classification of Diseases and Causes of Death National Center for Health Statistics, Center for Disease Control and Prevention, USA 2011.

[5] Report of the ISI Committee on Future Directions, ISI Permanent Office, October 1979.

[6] ISI Declaration on Professional Ethics, 1985, revised 2010. ISI Website: https://www.isi-web.org/index.php/news-fromisi/150-ethics-intro.

[7] The ISI Advisory Board on Ethics, 2010 ISI Website: https:// www.isi-web.org/index.php/activities/professional-ethics/isiadvisory-board.

[8] Bodin J.-L. The Fundamental Principles of Official Statistics, the Breakthrough of a New Era, Chapter 5 of the book "50 years of the Conference odf European Statisticians", UN Geneva, 2003.

[9] Resolution on the Fundamental Principles of Official Statistics, with revised preamble 2013. UN Website: https://unstats.un. org/unsd/dnss/gp/FP-Rev2013-E.pdf.

[10] Measuring Human Rights and Democratic Governance, OECD Journal on Development, 9(2), 2008.

\footnotetext{
${ }^{17} 135$ years since the creation of the ISI in 1885 and 167 years since the 1st International Statistical Congress in 1853.
} 